\title{
The Impact of Irregular Qiraat on Arabic Semantics and Dialects
}

Mohamed Fathy Mohamed Abdelgelil, Hasan. A. F., Yusoh. F, Ismail. F. Z., Ab Rashid. R, Ab Aziz. N. S., Hassan. A

To Link this Article: http://dx.doi.org/10.6007/IJARBSS/v11-i7/10670

DOI:10.6007/IJARBSS/v11-i7/10670

Received: 22 May 2021, Revised: 24 June 2021, Accepted: 15 July 2021

Published Online: 27 July 2021

In-Text Citation: (Abdelgelil et al., 2021)

To Cite this Article: Abdelgelil, M. F. M., Hasan, A. F., Yusoh, F., Ismail, F. Z., Ab Rashid, R., Ab Aziz, N. S., Hassan, A (2021). The Impact of Irregular Qiraat on Arabic Semantics and Dialects. International Journal of Academic Research in Business and Social Sciences, 11(7), 1672-1676.

Copyright: (c) 2021 The Author(s)

Published by Human Resource Management Academic Research Society (www.hrmars.com)

This article is published under the Creative Commons Attribution (CC BY 4.0) license. Anyone may reproduce, distribute, translate and create derivative works of this article (for both commercial and non-commercial purposes), subject to full attribution to the original publication and authors. The full terms of this license may be seen

at: http://creativecommons.org/licences/by/4.0/legalcode

Vol. 11, No. 7, 2021, Pg. 1672 - 1676

Full Terms \& Conditions of access and use can be found at http://hrmars.com/index.php/pages/detail/publication-ethics 


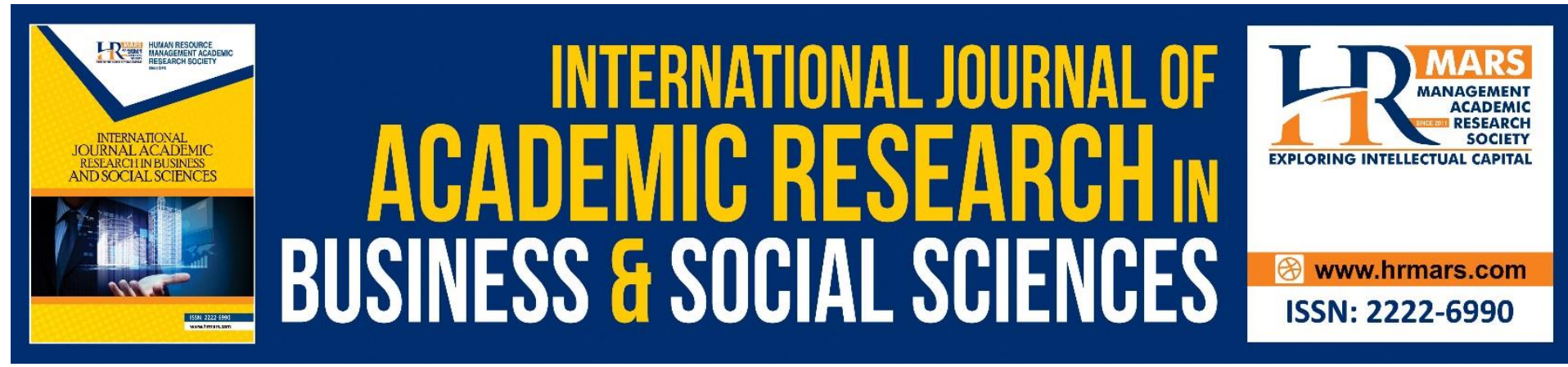

\title{
The Impact of Irregular Qiraat on Arabic Semantics and Dialects
}

\author{
Mohamed Fathy Mohamed Abdelgelil, Hasan. A. F., Yusoh. F, \\ Ismail. F. Z., Ab Rashid. R, Ab Aziz. N. S., Hassan. A
}

Faculty of Islamic Contemporary Studies (FKI), Sultan Zainal Abidin University (UniSZA),

21300, Terengganu, Malaysia.

Email: mfathy@unisza.edu.my

\begin{abstract}
Arabic semanticists and dialects scholars have paid considerable attention to Qiraat (the plural noun of Qiraah i.e. reading or recitation of the Holy Qur'an) and they often cite examples of irregular Quranic Qiraat in their rules and reasoning. However, many Qur'anic scholars may not be adequately aware of the significant impact of Quranic Qiraat on semantics as well as their role in preserving dialects of the Arab tribes. This paper aims to show the impact of irregular Qiraat on Arabic lexical semantics and Arabic dialects by tracking some examples of irregular Qiraat and examining how they preserved the Arabic dialects. The research adopted the analytical method in tracking the lexical features in irregular Qiraat and identifying the semantic differences between such lexical items in different Qiraat on the one hand and cite some examples from Qiraat that enriches meaning on the other. The findings indicate that irregular Qiraat are fundamental for standardizing linguistic rules. It is also found that irregular Qiraat has corroborated with several Arabic dialects and that is why Qiraat were in line with the Arab dialects during the era of Prophet Mohammed.
\end{abstract}

Keywords: Semantics, Arabic Dialects, Irregular Qiraat, Arabs.

\section{Introduction}

The Holy Quran with its irregular and Mutawatir (i.e. successive) Qiraat serves as an essential source of Arabic linguistics which were closely associated with the Quran since their development and standardization. Not only have the Arab linguists paid attention to Mutawatir Qiraat but they also drew inspiration from irregular Qiraat, and thus many renowned linguists have dedicated themselves to show the various aspects of irregular Qiraat and considered them as authoritative sources.

Looking into Arabic grammar references, we may find that most Arab grammarians and linguists view Mutawatir and irregular Qiraat as authoritative sources. Although not all linguists accepted irregular Qiraat in rules standardization, the majority of Arab linguists view irregular Qiraat as an authoritative source. 


\section{Preliminaries}

Although there exists a disagreement among jurists as to whether irregular Qiraat are authoritative sources in Shariah rulings, there is a consensus among Arab grammarians that irregular Qiraat are used as an authentic source. What is more is that irregular Qiraat are considered one of the essential elements for syntactic rules standardization, and they were used as a reference to resolve controversy amongst scholars as well as preserving the authentic Arabic dialects.

According to Al-Suyuti, "People frequently referred to irregular Qiraat as an authoritative source in Arabic as long as they were not in conflict with one of the established forms of Qiyas. In case of any conflict, the Qiraah would be accepted in such a specific issue without generalization. Moreover, the irregular Qirrah which was in conflict with Qiyas but came through multiple lines of narration was viewed as an authoritative source with no generalization. Therefore, referring to the irregular Qiraah as an authoritative source was adopted by all grammarians with no exception, though the matter is different when it comes to the field of fiqh (Al-Syuti, 1989; Abdelgelil, 2018)".

\section{Conceptual Linguistic Definition Dialects}

Dialects are a group of linguistic characteristics that belong to a certain environment and are shared by some individuals. Dialects are a branch of science that studies the different phenomena and factors related to the occurrence of speech forms in a language.

Based on the above definition, it can be argued that dialectology deals with linguistic phenomena that occur in one of the languages due to the difference in dialects, or in which the different dialects are a major reason. Examples may include "ibdal" (substitution), "idgham" (sound assimilation), "Hamza" and "tasheel" (eased Hamza), and issues with common, opposing, and synonymous contexts (Ebrahym, 1992; Abdelgelil, 2021).

\section{Semantics}

Semantics is the science that studies meaning or the branch of linguistics that deals with the theory of meaning. It is also that branch which studies the conditions that must be present in the symbol in order to be able to carry the meaning. Semantics is known to Arab scholars as the science of studying the meaning or the theory of meaning (Umar, 1998; Abdelgelil, 2019; Abdelgelil, 2020).

\section{The Impact of Irregular Qiraat on Semantics}

This refers to the impact of the irregular Qiraat on changing the connotations of the word and its meanings in terms of expansion, specialization, generalization, restriction, affirmation, clarification, as well as other features related to the semantic level of the Arabic language.

An example of this can be found in surah al-Masad: "Tabbat yada abi Lahabin watabb" (Cut off the hands of Abi Lahab! Cut off he!) (Qur'an, Al-Masad, 111: 1). Ibn Masoud, may Allah be pleased with him, read "Tabbat yada abi Lahabin waqadd tabb" (Cut off the hands of Abi Lahab! And certainly has he cut off!), using the statement style.

This irregular reading reveals the connotation of the mutawatir Qiraah, clarifies its meaning, and intensifies its connotation. According to the irregular Qiraah, "wa qadd tabb" (And certainly has he cut off) indicates that in the mutawatir Qiraah there is a supplication that he will cut off exactly as his hands at the beginning of the verse. Therefore, Ibn Masoud 
read the noble verse with an addition of the word "qadd" (certainly has) to indicate the realized and affirmed statement, since the Arabic word "qadd" refers to affirmation or realization if used with the past tense. Based on that, his hands were cut off from monotheism or good things (Al-Mawardi, 2007; Abdelgelil, 2018; Abdelgelil, 2020).

To explain further, (qadd) (certainly has) affirmed the realized and completed actions as in the noble qur'anic verse: "Qadd aflaha al Mu'munun" (The believers have already succeeded) (Qur'an, al-Mu'minun, 23: 1). The Arabic word "qadd" in this ayah refers to an affirmed and realized action because it was used with a past verb: (succeeded). In another example, Allah Almighty says (Certainly has Alläh heard the speech of the one who argues [i.e., pleads] with you, [O Muhammad], concerning her husband and directs her complaint to Allāh. And Allāh hears your dialogue; indeed, Allāh is Hearing and Seeing). (Al-Majadleh, 58: 1).

Based on this semantic corroboration of using (qadd) with the past verb, it may be stated that using the word in surah Al-Masad "Tabbat yada abi Lahabin watabb" (Cut off the hands of Abi Lahab and certainly has he been cut off) intensified the meaning by affirming that it was a realized statement while it refers to supplication in the mutawatir Qirrah without "qadd".

\section{The Impact of Irregular Qiraat on Dialects and Sounds}

A dialect is a group of linguistic characteristics that belong to a certain environment and are shared by individuals of this environment. Many Qur'anic Qiraat, whether mutawatir or irregular referred to these Arab dialects used by Arab clans and tribes. Examples include the noble verse: "qal ahaduhuma inni arani a'siru khamra" (Said one of them: "I see myself (in a dream) pressing wine.") (Qur'an, Yusuf 12:36).

According to the dialects of the people of Oman, "inab" (grapes) is another name for wine. Ibn Masoud and Ubay bin Kaab read: "Inni arani a'siru 'inaba" (I see myself (in a dream) pressing grapes). In another Qur'anic verse.

The Almighty says: "afala ya'lamu 'idha bu'thira ma fi alqubur?" (Does he not know when that which is in the graves is scattered abroad?) (Qur'an, Al-'Adiyyat, 100: 9). Ibn Mas'oud, in his irregular Qiraah, replaced the letter "Ain" with the letter "Ha" in (buhthira). As the two letters have the same articulation exit, the same articulation exit is used by some of the Arabs of bani Asad tribe for producing the two letters (Al-Khatib, 2000; Abdelgelil, 2018).

Mutawatir and irregular Qiraat are two of the Arab dialects that have the same meaning and connotation, and this confirms that irregular Qiraat have preserved many of the origins of classical Arabic dialects.

Arabic sounds are the alphabets from which words and structures are formed and which are studied in phonology or phonetic, in terms of their articulation exits, attributes, and how they are produced. Accordingly, the Arabic alphabet or the phoneme level of the Arabic language had their influence on irregular Qiraat. This argument can be shown in the noble verse: "watalhin mandud" (Among Talh trees with flowers (or fruits) piled one above another) (Talh (Al-Qur'an, al-Waqi'ah, 56: 29). The irregular Qiraat were influenced by the sounds in replacing the letter "Ha" with "Ain" as they come from the same exit. That's why, Ali bin Abi talib and Abdullah bin Mas'oud read it " watal'in", replacing the letter "Ha" with "Ain" (AlKhatib, 2000; Abdelgelil, 2019).

In another verse," falyawm nunajika bibadanika" ("This day shall We save thee in the body) (Qur'an, Yunus, 10: 92). In an irregular Qiraah, Imam Yazid Al-Yazidi read "nunahika" (throw your body on the seaside). This Qiraah was narrated by 'Alqamah from bin Mas'oud. 
In the mutawatir Qiraah, the word "nunajika" means "to put your body on a higher ground". The "Jeem" sound in "nunajika" changed to the "Ha" sound in "nunahika", and the meaning changed accordingly. So the meaning became to put your body on one side of the sea so that the people of Israel see it. His body was short and red as a bull (Al-Mawardi, 2007; Abdelgelil, 2020).

\section{Conclusion}

The findings of the research include the following:

- Irregular Qiraat play an essential role in the standardization of the Arabic language rules and foundations.

- Irregular Qiraat have corroborated with many Arabic dialects and were in line with them.

- Irregular Qiraat have preserved the heritage of authentic Arabic dialects.

- The impeded meaning was conveyed by the Qiraat which were in line with Arabic dialects during the Prophetic era.

\section{Acknowledgement}

Special thanks go to the Research Management, Innovation and Commercialization Centre (CREIM), Universiti Sultan Zainal Abidin.

\section{References}

Al-Quraan Al-karim.

Abdelgelil, M. F. M. (2020). Grammarians' Critique of Qur'anic Qira'at. International Journal of Academic Research in Business and Social Sciences, 10(11), 1225-1231.

Abdelgelil, M. F. M. (2020). Solving the Quranic Issues with Quranic Qira'at, International Journal of Academic Research in Business and Social Sciences, 10(12), 36-42.

Abdelgelil, M. F. M., Al-Janayni, M. U., Baru, R., Hamzah, M. S., Razali, M. A. T. M., \& Ismail, F. Z. (2018). Tawjih Al-Qira'at Based on Inscription, Language, and Unusual Modes of Recitation According to Ibn Zanjalah. International Journal of Academic Research in Business and Social Sciences, 8(10), 362-370.

Abdelgelil, M. F. M., Daud, N. B., Omar, N. B., Ismail, F. Z. B., \& Wahab, A. H. B. A. (2018). Taujeeh Al-Qira'at Using Qur'an, Hadith and Poetry according to Ibn Zanjalah. International Journal of Academic Research in Business and Social Sciences, 8(10), 371-379.

Abdelgelil, M. F. M., Musolin, M. H., Serour, R. O. H., Abdullah, M. S., \& Noor, M. N. M. (2018). Law and Moral Values in the Holy Quran. International Journal of Academic Research in Business and Social Sciences, 8(11), 445-451.

Abdelgelil, M.F.M, Razali. M.A, Hassan. A, Hasan. A.F, Idris. M.F.H and Masoud. A.S,Quranic Inimitability in Quranic Qiraat, International Journal of Management, 11(10), 2020, pp. 117-121.

Al-Khatib, A. (2000). "Mu'jam Al-Qiraat", Dimashq: Dar Saad Al-Din.

Al-Mawardi, A. M. (2007). "Al-Nukat Wa Al-Uyun", Bairut: Dar Al-Kutub Al- Iylmiyyah.

Abdelgelil, M. F. M. (2020). Grammarians' Critique of Qur'anic Qira'at. International Journal of Academic Research in Business and Social Sciences, 10(11), 1225-1231.

Al-Syuti, J. (1989). "Al-Iqtirah Fi Usul Al-Nahw", Dimashq: Dar Al-Qhalam.

Ebrahym, A. (1992). "Fy Allahjat Al-Arbiyyah", Cairo: Mktabah Ala-Ng/w Almasriyyah.

Umar, A. M. (1998). "Ilm Al- Dalalah", Kwait: Maktabah Lisan Al-Arab. 